\title{
Assessing the adverse effects of a mixture of AMD and sewage effluent on a sub-tropical dam situated in a nature conservation area using a modified pollution index
}

\author{
Petrus F. Oberholster ${ }^{1} \cdot$ Jaqueline Goldin $^{1} \cdot$ Yongxin $\mathrm{Xu}^{1} \cdot$ Thokozani Kanyerere $^{1} \cdot$ Paul J. Oberholster $^{1,2}$. \\ Anna-Maria Botha ${ }^{3}$ (D)
}

Received: 10 September 2020 / Revised: 17 December 2020 / Accepted: 18 January 2021 / Published online: 19 February 2021

(c) University of Tehran 2021

\begin{abstract}
Currently water resources in nature conservation areas are under severe pressure due to external drivers of anthropogenic pollution. There is a lack of monitoring tools to determine water quality status of dams situated in nature reserves receiving a mixture of pollutants over space and time. The present study was conducted over a 12-month period with the aim of applying a modified pollution index (PILD) to determine the water quality and phytoplankton status of the Loskop Dam situated in the Loskop nature reserve, South Africa. From the data generated in the current study, it was evident that the PILD effectively determined nutrient enrichment and heavy metal pollution in the dam. Furthermore, the study showed that the most pollution tolerant phytoplankton species was the diatom Melosira varians followed by the dinoflagellate Ceratuim hirundinella and the cyanobacteria Microcystis aeruginosa. Chemical variables during the sampling period that exceeded the limits of the South African, Canadian, Australia and New Zealand guideline levels were $\mathrm{Zn}, \mathrm{TP}, \mathrm{Cl}, \mathrm{Fe}, \mathrm{Mn}$ and $\mathrm{NH}$. The occurrence of concentrations of $\mathrm{Cl}$ above the target water quality range for aquatic ecosystems $\left(5 \mu \mathrm{gl} \mathrm{l}^{-1}\right) \mathrm{over}_{\mathrm{the}} \mathrm{entire}$ sampling period, may have been related to point source sewage pollution in the upper catchment. The PILD showed poor water quality conditions during the months of September and October during the dam's destratification (lake overturn). By modifying an existing index to incorporate physico-chemical variables that are strongly related to a mixture of pollutants, it should have application on global scale applied to different waterbodies with differ phytoplankton indicator species across different geographical regions. Furthermore, it could also in the future serve as a decision support tool for conservation managers to determine the pollution status of a dam situated in nature conservation areas receiving a mixture of pollutants.
\end{abstract}

Anna-Maria Botha

ambo@sun.ac.za

1 Department of Earth Sciences, Faculty of Natural Sciences, University of the Western Cape, Private Bag X17, Bellville 7535, South Africa

2 Centre for Environmental Management, University of the Free State, Private Bag 339, Bloemfontein 9300, South Africa

3 Genetics Department, Stellenbosch University, Private Bag X1, Matieland, Stellenbosch 7601, South Africa 


\section{Graphic abstract}

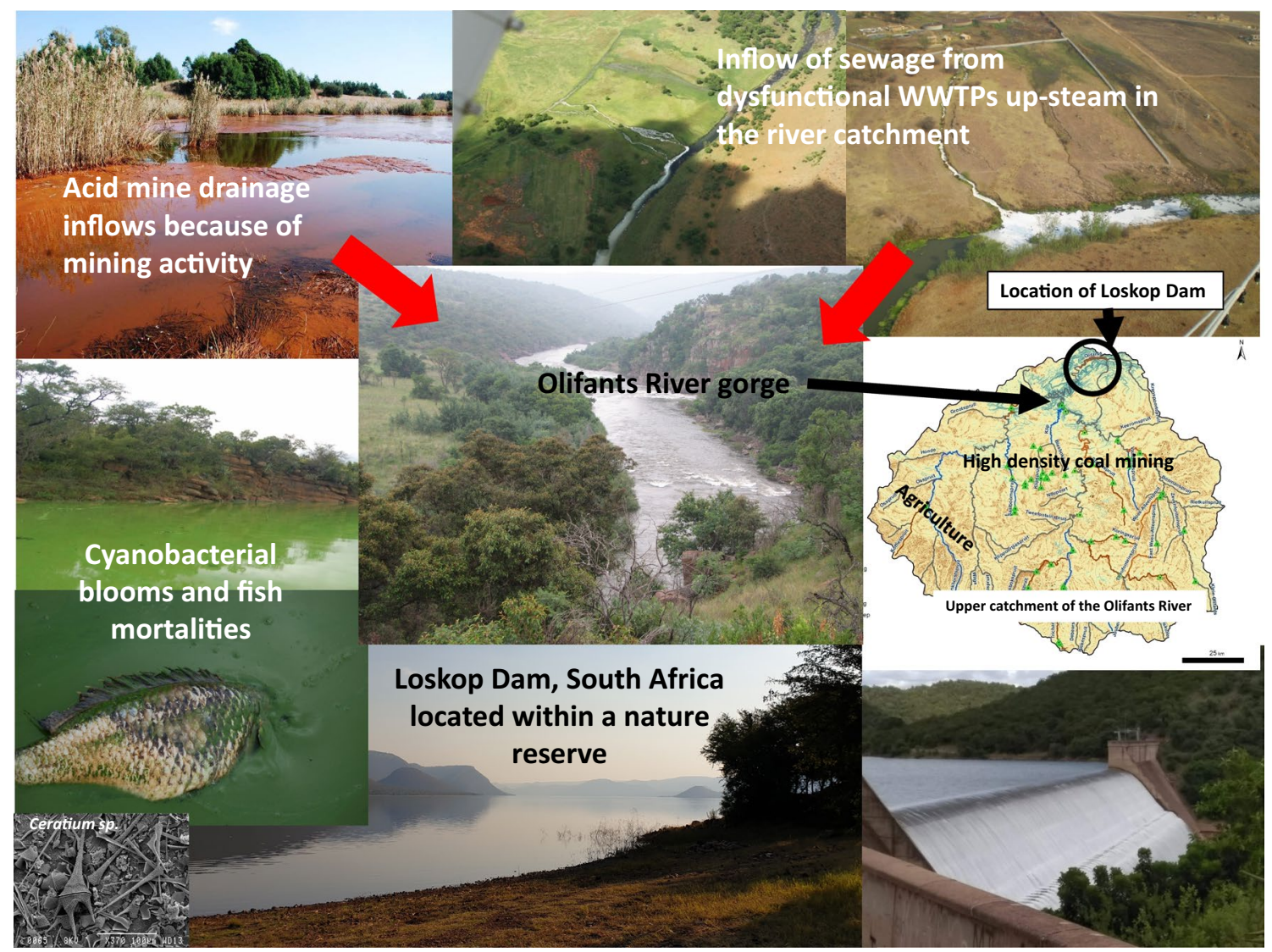

Keywords Conservation area $\cdot$ Mixture of pollutants $\cdot$ Modified pollution index $\cdot$ Phytoplankton

\section{Introduction}

Over the past two decades, isolated incidents of mass fish mortality have been recorded at different times in Loskop Dam, South Africa. These incidents have become more frequent during 2003-2008 (Dabrowski et al. 2013) and coincided with Nile crocodile (Crocodylus niloticus) and terrapin (Pelomedusa subrufa) mortalities. The crocodile population in Loskop Dam has declined from approximately 30 animals to a total of 6 in 2008 (Dabrowski et al. 2013). Crocodile mortality in Loskop Dam during this time was ascribed to pansteatitis, which is associated with the intake of rancid fish fat after a fish die-off. During 2008, the crocodile population in the Olifant's River Gorge downstream of Loskop Dam in the Kruger National Park, which is one of the largest conservation areas in Africa, declined from 1000 to 400. Furthermore, Loskop Dam also showed signs of eutrophication conditions over the last two decades with large toxic cyanobacterial blooms occurring sporadically (Oberholster et al. 2010; Dabrowski 2014).
Land use in the catchment is dominated by extensive coal mining in the Witbank Coalfields, which are located in the headwaters of the Olifants River, upstream of Loskop Dam causing Acid Mine Drainage (AMD) (Oberholster et al. 2017; Lebepe et al. 2020). Heavy metals from the latter can be a risk to the eco-environment and human health (Kumar et al. 2020a, 2020c). With the latter background in mind, we proposed to develop a pollution index that can assist conservation managers globally to monitor polluted dams in conservation areas using Loskop Dam as a case study.

Numerous biological assessment tools have been developed globally for different types of aquatic ecosystems and for various monitoring purposes (Bain et al. 2000; Simon 2000; Kumar et al. 2020b). Making use of bio-indicators, species may prove an accurate description of the status and cumulative deterioration of an aquatic ecosystem (CastroRoa and Pinilla-Agudelo 2014). Phytoplankton are of key ecological importance because of the major role they play in aquatic food web interactions. Phytoplankton communities are extremely dynamic and respond to changes in light, nutrients and sediment loads, rapidly changing in biomass 
distribution and species composition; thereby, making them good indicators of aquatic health and water quality (CastroRoa and Pinilla-Agudelo 2014).

Currently, there is an urgent need to generate instruments (e.g., monitoring indices) that can help to preserve threatened aquatic ecosystems in nature reserves and to identify and prevent the contamination of watersheds. The following characteristics are important indicators of a good index: (1) The index must focus both on physico-chemical parameters and biological indicators. Biological and chemical indicators all provide information about a waterbody. A biological index, in the absence of other supporting information, can provide significant insight into the degree of stress to which a waterbody is subjected. (2) The index can be applied to study a complex aquatic ecosystem by giving biological communities each a single numerical value to indicate their resilience towards contamination. A common occurring problem with most indices, for example that of Kothe's, is that it only takes into account the response of a single taxon to assess the condition of a sample site, which could include "suspect" species that can tolerate pollution. (3) Most of the indices that has been developed for biological monitoring focused only on river organisms. This meant that the pollution index might not provide informative data for assessment if applied to a stationary water body such as lakes, dams and ponds. Therefore, a good pollution index must be flexible so that it can be modified to assess different types of waterbodies, as well as using different indicator species.

The pollution index developed by Jiang and Shen (2003) for example, was first used to assess protozoan communities in the River Hanjiang, China. The method was then modified by Costro-Roa and Pinilla-Agudelo (2014) to assess the condition of five wetlands in Bogotá and one rural wetland (Brazilia) during which they used diatoms as indicators of pollution. (4) Most indices make use of limited data sets. When using this method there is flexibility in the type of data that can be collected and combined. In the studies of Kumar et al. (2020a and b) more than one method was utilised to provide a better assessment. As previously stated, most indices only focus on one specific aspect to assess aquatic pollution, so more than one pollution index needs to be implemented to have a greater understanding on the level of pollution (Mishra et al. 2016). When utilising the chosen method, the assessment is more comprehensive as it incorporates both the biological organisms that act as "indicators" of pollution and the national and international standards to assess physico-chemical contamination. (5) The index must have the ability to make use of any organisms as "bio-indicators". According to Bellington et al. (2010) most of the other indices utilising bio-indicators only use diatoms, such as the indices of Sládeček (1986) and Kelly and Whitton (1995). This means that these only focus on one specific group of organisms. Palmer's index (1969) for example makes use of bio-indicators, but the index only focusses on a selected group of species which only indicates organic pollution. In a complex aquatic system where different sources of contamination (i.e., mixture of AMD and sewage effluent) are present, it is important to select the best index or to modify an existing index to generate the best results.

Although not much is known about the mixture of AMD and sewage effluent under reservoir conditions, the treatment of AMD by municipal wastewater is a well-documented principle (Roetman 1932; McCullough et al. 2008). An earlier study by McCullough and Lund (2011) investigated the treatment of AMD using sewage and green yard waste as organic source to reduce sulphate concentrations in microcosm experiments, containing pit lake water with a $\mathrm{pH}$ of 2.4. The authors found higher bioremediation rates in AMD treated with sewage than green yard waste. In multi-stage studies of co-treatment of synthetic AMD and municipal wastewater conducted by Strosnider et al. (2011a; b), the authors reported the decrease in $\mathrm{Al}, \mathrm{As}, \mathrm{Cd}, \mathrm{Fe}, \mathrm{Mn}, \mathrm{Pb}$ and $\mathrm{Zn}$ by $99.8 \%, 87.8 \%, 97.7 \%, 99.8 \%, 13.9 \%, 87.9 \%$ and $73.4 \%$, respectively, with a net acidic influent conversion to net alkaline circumneutral effluent. The system received municipal wastewater with a mean $\mathrm{BOD}_{5}$ of $265 \mathrm{mgl}^{-1}$ and produced effluent with a $\mathrm{BOD}_{5}$ below detection limit.

The objectives of the current study were: (1) to apply a modified pollution index to determine the status of the water quality of a dam situated in a nature reserve receiving a mixture of AMD and sewage effluent, and (2) to determine if this index tool can be used as a decision support tool for conservation managers by identifying changes in waterbody water quality over space and time.

\section{Materials and methods}

\section{Study area}

South Africa possesses approximately five percent of the global recoverable coal reserves and is also the world's sixth largest coal producer. The Witbank coalfields, in Mpumalanga Province, South Africa, represent the largest area of active coal mining in the country and are located in the Olifants River catchment, resulting in the river being considered to be one of the most polluted rivers in southern Africa (Lebepe et al. 2020). Mining activity causes mine dewatering which results in a discharge of approximately $50 \mathrm{Ml}$ per day of mine water into the upper Olifants River catchment (Dabrowski et al. 2014). Other land use activities in the upper catchment that have major impacts on water resources are effluent from wastewater treatment plants (WWTPs). Thirtytwo of the WWTPs are not operated optimally according to the National Green Drop (GD) Report of 2010 (DWA 2010; Oberholster et al. 2013). It was evident from this National 
Green Drop report that most of the WWTP's in the upper catchment had an overall score of less than $30 \%$, showing that many of these plants are in a critical, dysfunctional state. In a previous study by Oberholster et al. (2017) the authors demonstrated that although neutralization of AMD and acid precipitation by sewage effluent were evident in the upper Olifants River catchment, the deterioration in environmental conditions and associated shifts in biological communities were distinct. In the upper Olifants catchment, the Loskop Dam (25 26' 57. 05" S; $29^{\circ} 19^{\prime} 44.36$ E) acts as a repository for these pollutants and was selected as current case study (Grobler 1994) (Fig. 1). The sub-tropical dam is surrounded by 23612 ha of nature reserve and contains a number of protected species, e.g., the White Rhino.

\section{Physical, Chemical and Phytoplankton Sampling of Loskop Dam}

Sampling was conducted on a monthly basis over a period of one year (January 2016-December 2016). On each of the sampling visits water temperature, $\mathrm{pH}$ and electrical conductivity values were measured in situ, using a Hach sensionTM 156 portable multiparameter (Loveland, USA). Dam water was sampled on a monthly basis using a six-litre Von Dorn sampler at a depth of $1.5 \mathrm{~m}$ at the dam wall. The latter depth was selected to capture phytoplankton in the photic zone. The sampled dam water was then divided in three subsamples of $2 \mathrm{~L}$ each for the following analyses: (a) Two litres were filtered through $0.45 \mu \mathrm{m}$ pore size Whatman GF/filters for dissolved nutrient analyses; (b) Two litres were filtered through $1 \mu \mathrm{m}$ Gelman glassfibre filters and preserved in nitric acid for metal analyses; and (c) Two litres was preserved in the field by addition of acidic Lugol's solution to a final concentration of $0.7 \%$, followed after one hour by the addition of buffered formaldehyde to a final concentration of $2.5 \%$ for phytoplankton identification. All sampled water was stored in polyethylene bottles that had been pre-rinsed with dilute sulphuric acid (to $\mathrm{pH}$ 2.0). The Standard Methods for the Examination of Water and Wastewater (APHA 1992) were used to determine the physico-chemical characteristics of the collected Dam water (standards, acceptable limits of the water quality and analytical methods are summarised in Table S1).

\section{Phytoplankton Identification}

All algal identifications were made with a compound microscope at $1250 \times$ magnification (van Vuuren et al. 2006; Taylor et al. 2007; Wehr and Sheath 2003). Strip counts were made until at least 300 individuals of each of the dominant phytoplankton species had been counted. All counts were based on the numbers of cells observed and the individual species were grouped into major algal groups (Lund et al. 1958; Willen 1991). The Berger-Parker dominance index

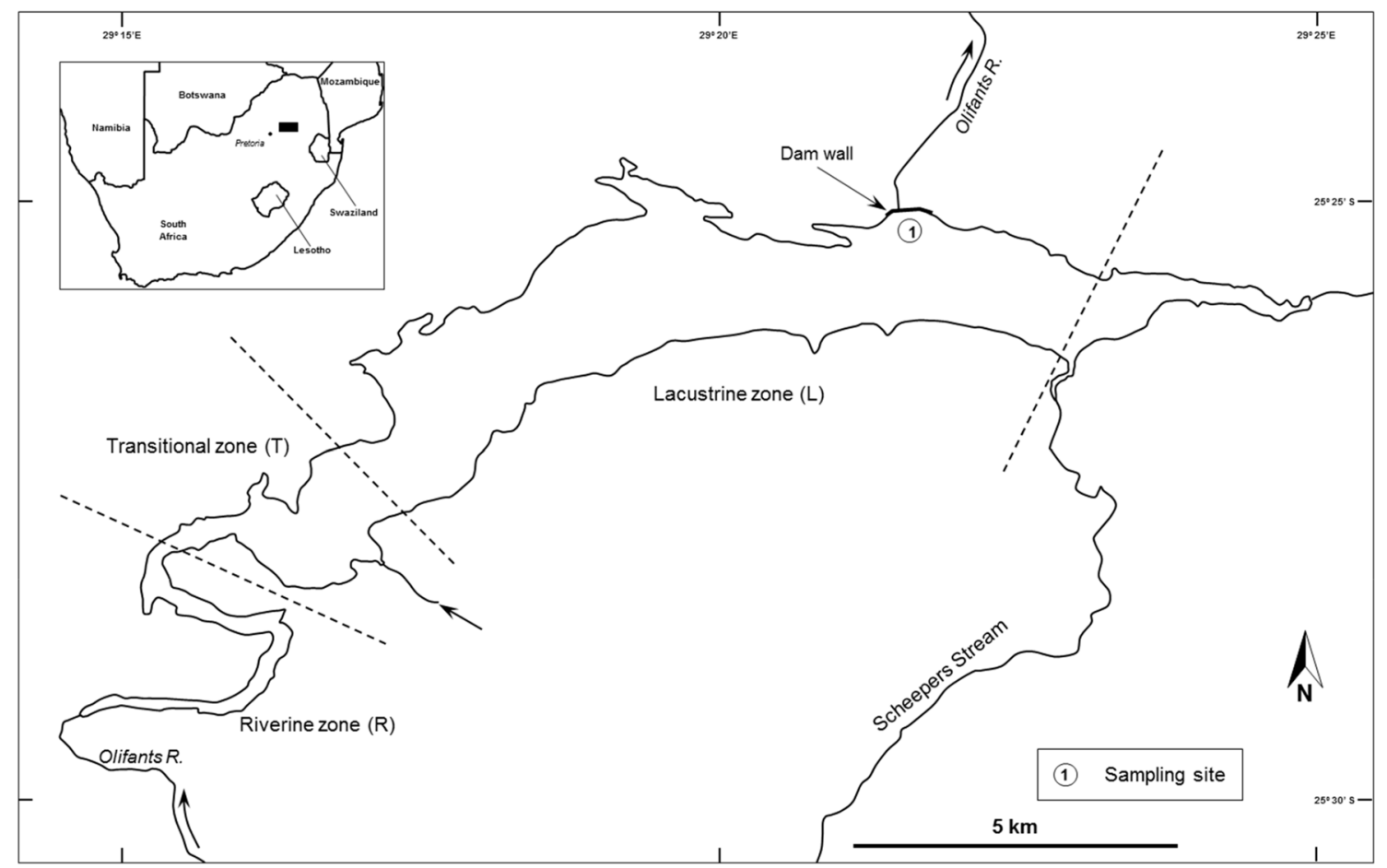

Fig. 1 Map of Loskop Dam showing the location of sampling site 1 and the position of the inflowing Olifants River. Inset shows the location of the map area in South Africa 
(Berger and Parker 1970) was used to measure the evenness or dominance of each algal species using the following equation:

$D=N_{\max } / N$

where $N_{\max }=$ the number of individuals of the most abundant species present in each sample and $N=$ the total number of individuals collected at each site.

\section{Pollution Index}

To apply a pollution index $(P I)$, a combination of the methods as detailed by Castro-Roa and Pinilla-Agudelo (2014) and Jiang and Shen (2003) was applied. Jiang and Shen (2003) first used the index to assess protozoan communities in the River Hanjiang, China. The latter method was modified by Costro-Roa and Pinilla-Agudelo (2014) to assess the condition of five wetlands in Bogotá and one rural wetland (Brazilia) during which they used diatoms as indicators of pollution. In the current study the index was modified to be used in a sub-tropical reservoir using phytoplankton as indicators of organisms. The index is based on three steps. The first step was to calculate the pollution values of the physico-chemical variables of Loskop Dam (for each month) using the following formula:

$P I=\sum_{i=1}^{n} \frac{C}{C L}$

where $C$ is the measured value of the variable in Loskop Dam and $C L$ is the limiting value of the variable and based on the aquatic system guidelines [Department of Water Affairs and Forestry (1996) legislation, Canadian and ANZECC (2000) guidelines]. The selected variables used in this calculation were Aluminium, Copper, Iron, Manganese, Total Phosphorus, Sulphates, Electric Conductivity, Zinc and $\mathrm{pH}$. The surface water variables were selected on the bases of their association with AMD and sewage pollution. The sum of the PI values for each of the physico-chemical variables provides an individual $P I$ for Loskop Dam, which can vary according to the months of the year. The $P I$ value for each selected variable in a month was added together to give a total $P I$ value of that month of the study.

The next step was to calculate the pollution value for each taxon $(P V T)$ for all the months of the year. The formula used is then:

$P V T=\frac{\sum_{i=1}^{n}\left(\frac{P I}{s}\right)}{N}$

where $n$ is the number of measured physico-chemical variables, $P I$ is the value calculated above, $N$ is the number of sample sites used in the study (Castro-Roa and PinillaAgudelo 2014) and $s$ is total months of the study period. To choose upper (most pollution tolerant algae species) and lower (most pollution sensitive algae species) PVT limits, the total $P I$ value for each month was calculated. The next step was to add total months of which certain species were present and then to divide this by $s$. According to the index the $P V T$ value represents the phytoplankton species tolerance towards pollution, which means the higher the phytoplankton species $P V T$ value, the more tolerant it is towards pollution.

The last step was to calculate the pollution value for the algae community of the Loskop Dam for each month according to the following formula:

$P I L D=\frac{\sum_{i=1}^{n}(P V T) i}{n_{s}}$

During the calculation $n_{s}$ is the total number of species, $P V T$ is the value calculated for each species and $i$ represents presence of the species at Loskop Dam. This value is an indicator of the level of pollution of the Loskop Dam for the corresponding months. To have a better representation of the PILD calculated for the phytoplankton community, a percentage conversion was calculated, where $100 \%$ corresponded to the highest values of the PILD site. The obtained value was subtracted from the total phytoplankton value.

\section{Statistical Analysis}

Principal component analysis (PCA) was used to identify spatial and temporal differences of the different events based on the abundance of the algal community, as well as the different water quality parameters measured; thus, highlighting certain (dis)similarities (Shaw 2003).

\section{Results}

\section{Physico-Chemical Parameters}

The average $\mathrm{pH}$ values over the 12-month sampling period ranges between 7.0 and 8.0. Variation in electric connectivity (EC) concentrations was observed throughout the study period from January 2016 to December 2016. Based on Table 1, EC levels were $43.9 \mathrm{mS} / \mathrm{m}$ in January and $43.5 \mathrm{mS} / \mathrm{m}$ in February 2016. However, EC concentrations increase during dam destratification (i.e., temperature induced water column mixing, Wetzel 1983) in March to $46.5 \mathrm{mS} / \mathrm{m}$. During the months that follow there was a steady incline with some fluctuations in EC level with the month of July having an EC concentration of $52.7 \mathrm{mS} / \mathrm{m}$, whilst the highest EC (63.5 mS/m) was measured during December 
Table 1 The average physical and chemical parameters measured from January 2016 to December $2016(n=12)$

\begin{tabular}{|c|c|c|c|c|c|c|c|c|c|c|c|c|c|}
\hline \multirow[t]{2}{*}{ Parameters } & \multirow[t]{2}{*}{ Units } & \multicolumn{12}{|l|}{ Months } \\
\hline & & Jan & Feb & Mar & Apr & May & Jun & Jul & Aug & Sept & Oct & Nov & Dec \\
\hline $\mathrm{Ph}$ & @ $25^{\circ} \mathrm{C}$ & 7.5 & 8.1 & 7.7 & 7.4 & 7.0 & 7.5 & 7.7 & 7.9 & 7.9 & 8.0 & 7.9 & 7.7 \\
\hline $\mathrm{EC}$ & $(\mathrm{mS} / \mathrm{m})$ & 43.9 & 43.5 & 46.5 & 46.9 & 47.8 & 49.3 & 52.7 & 56.5 & 58.0 & 57.6 & 60.3 & 63.5 \\
\hline $\mathrm{Na}$ & $m g 1^{-1}$ & 25.9 & 25.6 & 28.5 & 25.3 & 28.3 & 28.5 & 32.8 & 32.3 & 33.1 & 33.0 & 39.0 & 39.8 \\
\hline K & $\mathrm{mg}^{-1}$ & 6.9 & 7.8 & 6.6 & 6.4 & 7.5 & 6.7 & 7.0 & 7.1 & 6.7 & 7.1 & 6.8 & 8.3 \\
\hline $\mathrm{Ca}$ & $\mathrm{mg}^{-1}$ & 31.5 & 29 & 30.5 & 30.5 & 34.9 & 30.7 & 32.8 & 36.9 & 34.4 & 35.0 & 32.7 & 36.1 \\
\hline $\mathrm{Mg}$ & $\mathrm{mg}^{-1}$ & 19.0 & 16.4 & 17 & 17.7 & 19.1 & 17.5 & 19.7 & 19.6 & 20.3 & 19.1 & 19.2 & 20.4 \\
\hline $\mathrm{Fe}$ & $\mathrm{mg}^{-1}$ & 0.01 & $0.11 * *$ & 0.08 & 0.03 & 0.2 & 0.1 & 0.1 & 0.1 & 0.2 & $1.6^{* *}$ & 0.1 & 0.1 \\
\hline $\mathrm{Mn}$ & $m g 1^{-1}$ & 0.03 & 0.007 & 0.004 & 0.009 & 0.05 & 0.04 & 0.05 & $0.19 *$ & 0.06 & 0.07 & 0.07 & 0.05 \\
\hline $\mathrm{Cl}$ & $m g 1^{-1}$ & $18.0^{*}$ & $20.0 *$ & $20.0^{*}$ & $19.0^{*}$ & $20.0 *$ & $17.0 *$ & $25.0 *$ & $24.8^{*}$ & $29.3^{*}$ & $27.0 *$ & $27.0 *$ & $28.0 *$ \\
\hline $\mathrm{SO}_{4}$ & $\mathrm{mg}^{-1}$ & 140.0 & 127.0 & 125.0 & 123.0 & 158.0 & 125.0 & 157.0 & 152.0 & 162.0 & 168.0 & 178.0 & 208.0 \\
\hline B & $\mathrm{mg}^{-1}$ & 0.07 & 0.03 & 0.07 & 0.03 & 0.1 & 0.09 & 0.1 & 0.12 & 0.22 & 0.1 & 0.12 & 0.09 \\
\hline Alkalinity & $m g 1^{-1}$ & 61.0 & 58.025 & 59.0 & 57.0 & 61.0 & 65.0 & 66.0 & 43.03 & 14.0 & 64.0 & 49.842 & 62.0 \\
\hline Hardness & $m g 1^{-1}$ & 156.97 & 139.86 & 146.45 & 149.29 & 165.98 & 148.89 & 162.96 & 172.81 & 169.44 & 166.03 & 160.54 & 174.12 \\
\hline $\mathrm{Al}$ & $\mathrm{mg}^{-1}$ & 0.002 & 0.007 & 0.001 & 0.003 & 0.05 & 0.04 & 0.0011 & 0.006 & 0.03 & 0.05 & 0.021 & 0.04 \\
\hline $\mathrm{Cu}$ & $m g 1^{-1}$ & 0.001 & 0.002 & 0.03 & 0.002 & 0.04 & 0.04 & 0.03 & 0.03 & 0.01 & 0.04 & 0.03 & 0.04 \\
\hline $\mathrm{Zn}$ & $\mathrm{mg}^{-1}$ & 0.005 & 0.008 & 0.02 & 0.01 & $0.05^{* *}$ & 0.04 & $0.05^{* *}$ & 0.04 & 0.01 & $0.05^{* *}$ & $0.04 * *$ & $0.05^{* *}$ \\
\hline TP & $\mathrm{mg}^{-1}$ & $0.07 * * *$ & $0.06 * * *$ & 0.02 & 0.01 & 0.02 & $0.08 * * *$ & 0.02 & 0.03 & $0.1 * * *$ & $0.13 * * *$ & 0.03 & 0.02 \\
\hline $\mathrm{NH}_{4}-\mathrm{N}$ & $m g 1^{-1}$ & $0.32 * * *$ & $0.14 * * *$ & $0.18 * * *$ & $0.3 * * *$ & $0.29 * * *$ & $0.3 * * *$ & $0.3 * * *$ & $0.32 * * *$ & $0.28 * * *$ & $0.59 * * *$ & $0.3 * * *$ & $=0.11 * *$ \\
\hline $\mathrm{NO}_{3}-\mathrm{N}$ & $\operatorname{mg~} 1^{-1}$ & 0.009 & 0.03 & 0.01 & 0.06 & 0.37 & 0.38 & 0.38 & 0.37 & 0.39 & 0.44 & 0.39 & 0.41 \\
\hline Temp & ${ }^{\circ} \mathrm{C}$ & 6.3 & 9.7 & 9.8 & 7.6 & 8.2 & 6.8 & 9.0 & 0.9 & 6.0 & 7.7 & 9.7 & 9.4 \\
\hline $\mathrm{Si}$ & $\mathrm{mg}^{-1}$ & 0.83 & 0.8 & 0.63 & 0.91 & 1.1 & 0.84 & 0.48 & 0.21 & 0.26 & 0.21 & 0.22 & 0.62 \\
\hline
\end{tabular}

TWQR Target water quality range for aquatic ecosystems according to DWAF (1996)* or CCME (2012)** for aquatic ecosystems and the ANZECC (2000) guidelines for conservation aquatic areas ***

2016 (Table 1). The aluminum (Al) and iron (Fe) concentrations remained the same at the sampling site throughout the study, with the highest concentrations recorded during May-October (Al: $0.05 \mathrm{mgl}^{-1}$ and Fe: $1.6 \mathrm{mg} \mathrm{l}^{-1}$ (Table 1) in comparison to the other months. Copper $(\mathrm{Cu})$ and Manganese $(\mathrm{Mn})$, both had lower concentrations in January 2016, but showed some similarity with Al concentrations (also low in January) in comparison with the other months. These start increasing from April onwards. During the study, $\mathrm{SO}_{4}$ concentrations ranged between 123 and $208 \mathrm{mg} \mathrm{l}^{-1}$ (Table 1) while total phosphates (TP) varied between 0.02 and $0.1 \mathrm{mg} \mathrm{l}^{-1}$. The TP concentration was the highest during the month of October $\left(0.13 \mathrm{mg} \mathrm{l}^{-1}\right)$ in comparison to other months, when there was a shift towards late spring early summer with destratification.

\section{Phytoplankton Community Structure}

A clear phytoplankton species succession was recorded for the sampling site in Loskop Dam from January to December 2016. During January and February, the dominant (Berger and Parker index: $4.23 ; 3.34)$ phytoplankton species was the cyanobacterial species Microcystis aeruginosa (Kützing ex Lemmermann), which is normally found in nutrient enriched lakes, ponds and reservoirs or slow-flowing eutrophic rivers. M. aeruginosa was replaced by the larger, slower-growing late summer species Ceratium hirundinella (Müller). $C$. hirundinella was the dominant (Berger and Parker index, $3.64 ; 3.21 ; 2.98$ and 2.67 ) phytoplankton species from March to June. According to Table 2, the diatom M. varians (Agargh) became prominant during the mid-winter month of July and stayed dominant (Berger and Parker index, 2.91; 2.54) until August 2016. The latter species was replaced by Cryptomonas erosa (Ehrenberg), which became the dominant (Berger and Parker index, 3.13) species during early spring in the Loskop Dam. In the month that followed a community of small and rapidly reproducing phytoplankton, Trachelomonas intermedia (Ehrenberg), became dominant. After an increase in temperature in October, the occurrence of the cyanobacteria Microcystis aeruginosa became more prominent for the months of November and December when blooms of the cyanobacteria $M$. aeruginosa were observed.

The diatom M. variant was present in 10 of the 12 months during the study period. This species was absent in the water column only during September and October. The months with the highest collection of phytoplankton species were February and March, while August, September and October had the lowest number of phytoplankton species (Table 2). 
Table 2 Dominant and present phytoplankton species collected over the 12-month $(n=12)$ period ( $D$ Dominant; $P$ Present)

\begin{tabular}{|c|c|c|c|c|c|c|c|c|c|c|c|c|c|}
\hline \multirow[t]{2}{*}{ Code } & \multirow[t]{2}{*}{ Algal species } & \multicolumn{12}{|c|}{ Months } \\
\hline & & Jan & Feb & Mar & Apr & May & Jun & Jul & Aug & Sep & Oct & Nov & Dec \\
\hline Aul & Aulacoseira granulate & & & & & & & & & & & & $\mathrm{P}$ \\
\hline Cera & Ceratium hirundinella & & $\mathrm{P}$ & $\mathrm{D}$ & $\mathrm{D}$ & $\mathrm{D}$ & $\mathrm{D}$ & & & & $\mathrm{P}$ & & $\mathrm{P}$ \\
\hline Cryp & Cryptomonas erosa & $\mathrm{P}$ & $\mathrm{P}$ & $\mathrm{P}$ & $\mathrm{P}$ & & & & & $\mathrm{D}$ & & & \\
\hline Сус & Cyclotella meneghiniana & $\mathrm{P}$ & $\mathrm{P}$ & & $\mathrm{P}$ & $\mathrm{P}$ & & $\mathrm{P}$ & & & & & \\
\hline Fra & Fragilaria crotonensis & & & & & & & & & & & $\mathrm{p}$ & $\mathrm{P}$ \\
\hline Mel & Melosira varians & $\mathrm{P}$ & $\mathrm{P}$ & $\mathrm{P}$ & $\mathrm{P}$ & $\mathrm{P}$ & $\mathrm{P}$ & $\mathrm{D}$ & $\mathrm{D}$ & & & $\mathrm{p}$ & $\mathrm{P}$ \\
\hline Mic & Microcystis aeruginosa & $\mathrm{D}$ & $\mathrm{D}$ & $\mathrm{P}$ & $\mathrm{P}$ & $\mathrm{P}$ & $\mathrm{P}$ & & & & & $\mathrm{D}$ & $\mathrm{D}$ \\
\hline Ooc & Oocystis rupestris & $\mathrm{P}$ & $\mathrm{P}$ & $\mathrm{P}$ & & & & & & & & & \\
\hline Ped & Pediastrum duplex & & $\mathrm{P}$ & & & & $\mathrm{P}$ & $\mathrm{P}$ & & $\mathrm{P}$ & & & \\
\hline Sce & Scenedesmus armatus & & & $\mathrm{P}$ & & & & & & & & & \\
\hline Tab & Tabellaria flocculosa & & & $\mathrm{P}$ & & & $\mathrm{P}$ & & & & & & \\
\hline Trac & Trachelomonas volvocina & & & & $\mathrm{P}$ & $\mathrm{P}$ & $\mathrm{P}$ & $\mathrm{P}$ & & & $\mathrm{D}$ & & \\
\hline
\end{tabular}

The second most prominent phytoplankton species observed was the cyanobacteria $M$. aeruginosa, which was present in the samples 8 out of the 12 months. M. aeruginosa was not present during the winter and spring months of July to October. The third most noticeable species was $C$. hirundinella, which was present during 7 of the 12 months. C. hirundinella was absent during the months of January, July, August, September and November. The diatom Aulacoseira granulata and the green algae Scenedesmus quadricauda were less common during the study period. According to Table 2, there was a variation of diatom species collected during the study period. However, only one diatom species $M$. variant was dominant in the winter months while the rest of the species were resent in low numbers.

\section{Phytoplankton in Relationship with Physico-Chemical Parameters}

Figure 2 illustrates phytoplankton species in association with physico-chemical parameters over the time period of 12 months. The ordination plot describes $52.51 \%$ of data variations, with $37.19 \%$ on the first axis of the biplot and $15.32 \%$ on the second axis. As illustrated by the biplot, the species $M$. variant, $C$. hirundinella and $M$. aeruginosa correlated strongly with the variables: alkalinity, $\mathrm{Si}$ and surface water temperature. Furthermore, there was a strong correlation between the metals $\mathrm{Cu}$ and $\mathrm{Zn}$, and the diatom species Fragilaria crotonensis. However, the metals Al and Fe did not correlate with any of the phytoplankton species observed during the study (Fig. 2).

\section{PILD Analyses of Loskop Dam}

The $P I$ calculated during the study varied between the different physico-chemical variables. As illustrated in Table 3, some of the values of physical and chemical parameters were higher in certain months in comparison to others, as seen by the $P I$ for $\mathrm{Cu}$ which fluctuated between the ranges of 3.33 and 133.33, while the element Mn fluctuated between 0.02 and 0.39 . Furthermore, most of the trace metals PI's increased between the months of April and May during dam destratification, which is linked to the evidence presented in Table 2. The highest $P I$ value was observed in October while the lowest was observed during the summer month of January 2016.

The $P I$ value for the trace metal Al was the highest during the months of May and October, while the metal $\mathrm{Cu}$ was the highest during the months of May, June, October and December. Furthermore, the $P I$ value for Fe was the highest during the months of May, September and October, whereas the highest $P I$ value for Mn was August. Additionally, the PI value for $\mathrm{Zn}$ was the highest during the months of May, July, October and December. The month with the highest PI for both TP and pH was October. However, during the summer month of December the highest $P I$ value was recorded for $\mathrm{SO}_{4}$ and $\mathrm{EC}$ in comparison to the other months.

During the current study, it was evident that the phytoplankton species differed ach in their sensitivity towards environmental conditions, and that some were more susceptible to the physico-chemical parameters chosen in the current study. As illustrated in Table 4, the less tolerant phytoplankton species to the selected variables were $S$. armatus (PVT 1.18), A. granulate (1.7) and Oocystis rupestris (1.63). Nevertheless, from the species collected during the study period the most pollution tolerant species were the diatom $M$. varians (9.94), followed by the dinoflagellate $C$. hirundinella (8.67) and the cyanobacteria $M$. aeruginosa (8.29). This observation was also supported by evidence in Table 2 which shows the presence of each species throughout the year.

Using Table 5 to reflect the different categories of pollution, it was evident that there was a fluctuation in the 
Fig. 2 A principal component analysis (PCA) biplot indicating the associations between algae assemblage and selected water quality parameters. The biplot includes a depiction of phytoplankton species (e.g., Melosira, Microcystis, Ceratuim,

Tabellaria, Trachelomonas,

Aulacosieira, Fragilaria,

Cyclotella, Oocystis, Scenedesmus and pediastrum), physical and chemical parameters (e.g., $\mathrm{pH}, \mathrm{TP}, \mathrm{B}, \mathrm{Fe}, \mathrm{Al}, \mathrm{Mn}, \mathrm{EC}, \mathrm{Si}$, Temp, $\mathrm{Cl}, \mathrm{K}, \mathrm{NA}, \mathrm{SO}_{4}, \mathrm{Cu}, \mathrm{Ca}$, $\mathrm{Zn}, \mathrm{NH}_{4}-\mathrm{H}, \mathrm{NO}_{3}-\mathrm{H}$ and Alkalinity) and the sampling months of the year (Jan, Feb, Mar, Apr, May, Jun, Jul, Aug, Sept, Oct, Nov and Dec). These three variables were compared with one another in the biplot
Biplot (axes F1 and F2: $52.51 \%$ )

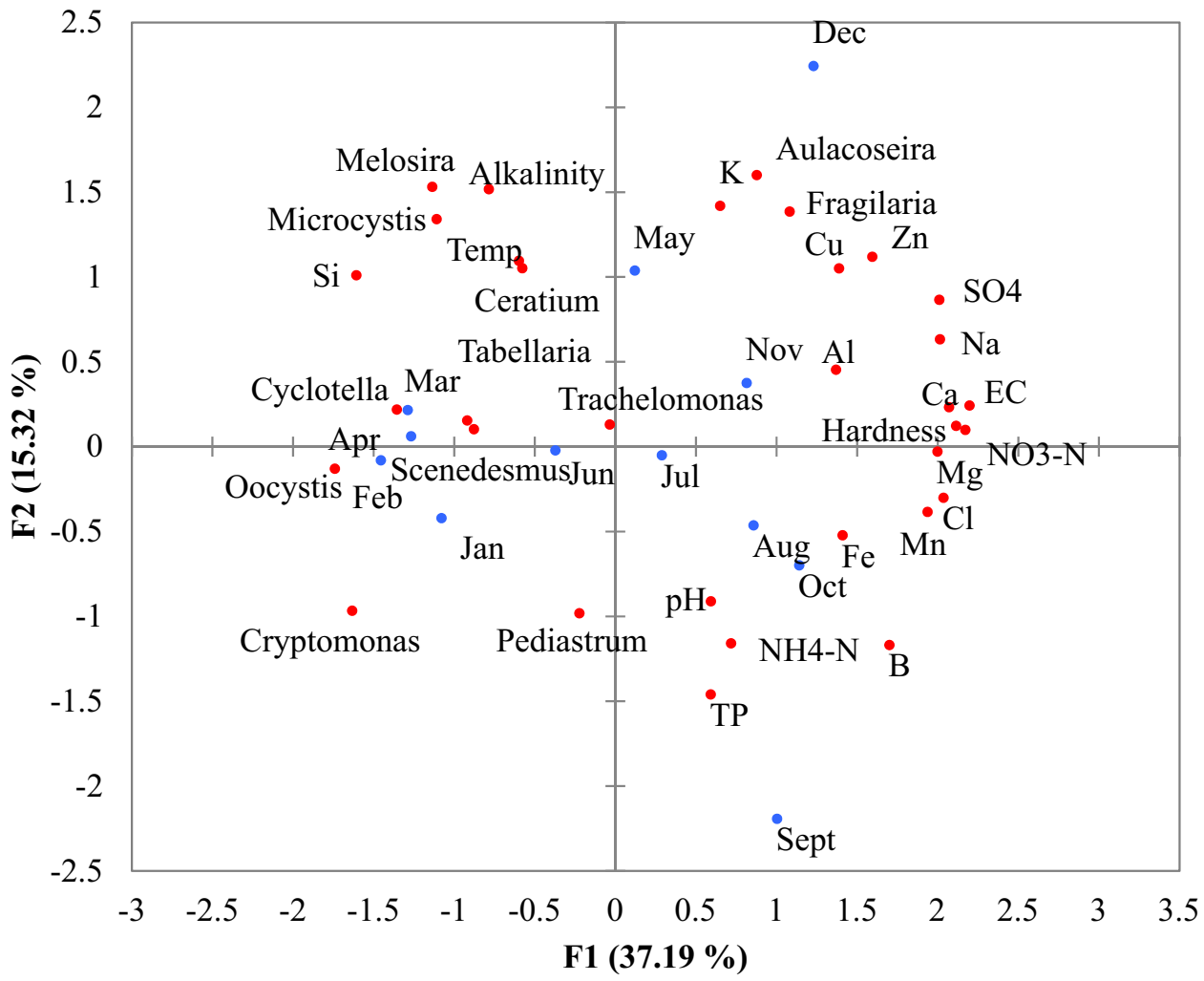

Table 3 PI values of physical and chemical parameters measured over a period of 12 months $(n=12)$ in Loskop Dam

\begin{tabular}{|c|c|c|c|c|c|c|c|c|c|c|c|c|}
\hline \multirow[t]{2}{*}{ PI values } & \multicolumn{12}{|c|}{ Months } \\
\hline & Jan & Feb & Mar & Apr & May & Jun & Jul & Aug & Sept & Oct & Nov & Dec \\
\hline $\mathrm{Al}$ & 0.4 & 1.4 & 0.2 & 0.6 & 10.0 & 0.8 & 0.22 & 1.2 & 6.0 & 10.0 & 4.2 & 0.8 \\
\hline $\mathrm{Cu}$ & 3.33 & 23.3 & 100.0 & 6.67 & 133.33 & 133.33 & 3.67 & 100.0 & 33.33 & 133.33 & 100.0 & 133.33 \\
\hline $\mathrm{Fe}$ & 0.1 & 1.1 & 0.8 & 0.3 & 2.0 & 1.0 & 1.0 & 1.0 & 2.0 & 2.0 & 1.0 & 1.0 \\
\hline $\mathrm{Mn}$ & 0.17 & 0.04 & 0.02 & 0.05 & 0.28 & 0.22 & 0.28 & 0.67 & 0.33 & 0.39 & 0.39 & 0.28 \\
\hline $\mathrm{Z}$ & 2.5 & 4.0 & 10.0 & 5.0 & 25.0 & 20.0 & 25.0 & 20.0 & 5.0 & 25.0 & 20.0 & 25.0 \\
\hline $\mathrm{EC}$ & 0.63 & 0.62 & 0.66 & 0.67 & 0.68 & 0.7 & 0.55 & 0.81 & 0.83 & 0.82 & 0.86 & 0.91 \\
\hline $\mathrm{pH}$ & 1.07 & 1.2 & 1.1 & 1.07 & 1.0 & 1.07 & 1.1 & 1.13 & 1.13 & 1.14 & 1.13 & 1.1 \\
\hline SO4 & 0.35 & 0.32 & 0.31 & 0.31 & 0.4 & 0.31 & 0.39 & 0.38 & 0.41 & 0.42 & 0.45 & 0.52 \\
\hline $\mathrm{TP}$ & 1.4 & 1.2 & 0.4 & 0.2 & 0.4 & 1.6 & 0.4 & 0.6 & 2.0 & 2.6 & 0.6 & 0.4 \\
\hline Total PI values & 9.95 & 33.18 & 113.49 & 14.87 & 173.09 & 159.03 & 32.61 & 125.79 & 51.03 & 175.7 & 128.63 & 163.34 \\
\hline
\end{tabular}

water quality condition of Loskop Dam throughout the year (Table 6). It was also evident that the water quality condition of the dam had progressively deteriorated over the 12-month period. The month with the highest PILD percentage was April (89\%) and the worst was October $(29 \%)$ during the destratification period.

\section{Discussion}

\section{Physico-Chemical Parameters}

It was evident from the current study that certain chemical 
Table 4 PVT value of each phytoplankton species observed over a 12-month period (January to December 2016) in Loskop Dam

\begin{tabular}{lll}
\hline Phytoplankton Species & Code & $P V T$ \\
\hline Aulacoseira granulate & Aul & 1.7 \\
Ceratium hirundinella & Cera & 8.67 \\
Cryptomonas erosa & Cryp & 2.32 \\
Cyclotella meneghiniana & Cyc & 2.75 \\
Fragilaria crotonensis & Fra & 3.04 \\
Melosira varians & Mel & 9.94 \\
Microcystis aeruginosa & Mic & 8.29 \\
Oocystis rupestris & Ooc & 1.63 \\
Pediastrum duplex & Ped & 2.87 \\
Scenedesmus armatus & Sce & 1.18 \\
Tabellaria flocculosa & Tab & 2.84 \\
Trachelomonas volvocina & Trac & 5.78 \\
\hline
\end{tabular}

variables sampled during the 2016 survey exceeded the standards set by the Target Water Quality Range for aquatic ecosystems according to DWAF (1996), CCME (2012) for aquatic ecosystems and the ANZECC (2000) guidelines for conservation aquatic areas. This could possibly be related to the prevailing drought conditions that persisted during the sampling period. These chemical variables were: $\mathrm{Fe}, \mathrm{Zn}, \mathrm{Cl}$ and $\mathrm{Mn}$; of which $\mathrm{Fe}$ is a significant indicator of AMD that originated from the upper Olifants River catchment. Based on measurements in the study, sulphate concentrations, also a good indicator of AMD, were always lower than the South African Water Quality Guideline value of $400 \mathrm{mg}^{-1}$ for domestic water usage (DWAF 1996).

A previous study by Cornet et al. (2014) on the Sancho Reservoir in Spain, also a reservoir receiving AMD, revealed that the waters of this reservoir present typical AMD characteristics, i.e., low $\mathrm{pH}$ and high concentrations of metals. However, pollution in the reservoir was less pronounced than that of the River Meca, whose waters flowed into it, due to dilution processes that occurred in the Sancho Reservoir. Additionally, there were various sources that caused an input of nutrients from the epilimnion layer of the Sancho Reservoir. Such nutrients may favour the growth of algae,
Table 6 General classification of the Loskop Dam according to the PILD over the study period January to December 2016

\begin{tabular}{lll}
\hline Months & PILD (\%) & $\begin{array}{l}\text { Interpretation based on } \\
\text { Phytoplankton species }\end{array}$ \\
\hline January & 61 & Contaminated \\
February & 85 & Slightly contaminated \\
March & 79 & Moderately contaminated \\
April & 89 & Slightly contaminated \\
May & 86 & Slightly contaminated \\
June & 81 & Moderately contaminated \\
July & 49 & Contaminated \\
August & 32 & Greatly contaminated \\
September & 8 & Greatly contaminated \\
October & 29 & Greatly contaminated \\
November & 51 & Contaminated \\
December & 76 & Moderately contaminated \\
\hline
\end{tabular}

increasing the DO. According to Peine and Peiffer (1998); Wendt-Potthoff and Neu (1998), phytoplankton photosynthesis activity leads to an increase in alkalinity in lakes and reservoirs. In the Sancho Reservoir, this may, in part, neutralize the acidity water received from AMD. Although in the current study, the metal concentrations in Loskop Dam were lower in comparison with that in the Cornet et al. (2014) study, a previous study by Oberholster et al. (2017) showed that the high loads of untreated sewage effluent are likely instrumental in neutralizing acidic conditions caused by AMD and acid precipitation in the upper catchment of Loskop Dam.

The occurrence of concentrations of $\mathrm{Cl}$ above the target water quality range for aquatic ecosystems $\left(5 \mu \mathrm{gl}^{-1}\right)$ (DWAF 1996), over the entire sampling period, may be related to point source sewage pollution. Chlorine is not normally a constituent of natural waters as it is too reactive to exist in the aquatic environment for long (DWAF 1996). However, large quantities of chlorine constituents are being introduced regularly into receiving waterbodies (Johnson and Jolley 1990; White 1992), a consequence of the practice of applying chlorine as an oxidizing agent and disinfectant in water purification and wastewater treatment plants. The presence

Table 5 Illustrates the different modified levels of contamination based on the findings of the PILD (Modified table after Castro-Roa and PinillaAgudelo (2014)

\begin{tabular}{|c|c|c|}
\hline PILD (\%) & Interpretation & Implications \\
\hline$>85$ & Slightly contaminated & High phytoplankton diversity. Dam with good or acceptable limnological conditions \\
\hline $65-85$ & Moderately contaminated & Signs of nutrient enriched. Dam with intermediate limnological conditions \\
\hline $33-65$ & Contaminated & $\begin{array}{l}\text { Only pollution resistant species in abundant. Sensitive species reduced. Dam with deficient limnological } \\
\text { conditions }\end{array}$ \\
\hline$<33$ & Greatly contaminated & $\begin{array}{l}\text { Only a few tolerant phytoplankton species dominant. Very reduced phytoplankton diversity. Dam with } \\
\text { poor limnological conditions }\end{array}$ \\
\hline
\end{tabular}


of chlorine in natural waters can have potentially severe consequences for aquatic flora and fauna (Dallas and Day 1993).

The limit guideline values exceeded by $\mathrm{NH}_{4}$ and TP concentrations measured in Loskop Dam was possibly the outcome of inactive and/or badly maintained wastewater treatment plants found upstream from Loskop Dam (Oberholster et al. 2013). Adding to this, non-point return flows from agricultural activities in the Olifants River catchment, may also have caused nutrient enrichment. This supported the findings of Dabrowski (2014), which by applying the SWAT (Soil and Water Assessment Model) to predict orthophosphate loads in the upper Olifants catchment, showed that poorly operating WWTWs were major contributors to catchment nutrient enrichment.

\section{Phytoplankton Community Responses}

In temperate zone lakes, oligotrophic systems support minimal phytoplankton biomass with low species diversity, while eutrophic and hypereutrophic lakes sustain very high average algal biomass often dominated by very few taxa, usually cyanobacteria, diatoms or in some waterbodies, dinoflagellates (Jensen and Pedersen 1994). In the current study, it was evident that the dominance of certain phytoplankton species was strongly related to specific environmental conditions. Most field observations showed more than 1-3 dominant species at any phase of seasonal development as predicted by the competitive exclusion theory (Hardin 1960). The reasons for this dominance of the phytoplankton species is because phytoplankton respond differently to frequent disturbances or changes in abiotic resource conditions of the waterbody (Reynolds 1984). The dominance of a phytoplankton species depends on (1) how the disturbances and change in abiotic resource conditions between a 200 and $20 \mathrm{~h}$ period interact with the phytoplankton growth rate and (2) the frequent occurrences of disturbances and changes during a 10 day interval. The interaction between the change in condition and the phytoplankton species can eventually initiate a successional sequence in phytoplankton development and lead to one phytoplankton species being more dominated. The dominance of the cyanobacterial species $M$. aeruginosa during the summer months of January, February and December 2016, correlated strongly with alkalinity and temperature (Fig. 2).

According to Kruger and Eloff (1978) a strong correlation exists between the surface water temperature and the development of $M$. aeruginosa blooms in eutrophic reservoirs in South Africa. From their observations, Kruger and Eloff (1978) suggested that the low surface water temperatures in the South African Highveld reservoirs, as in the case of Loskop Dam during winter months $\left(7-8{ }^{\circ} \mathrm{C}\right)$, may be a barrier to the growth of bloom forming cyanobacterial species. The increases of $M$. aeruginosa during the summer months are likely related to the higher water temperatures since phosphorus recycling (number of phosphorus molecules recycled per unit time) is more intensive in warmer waters, while processes of phosphorus release from lake sediment and mineralization are highly temperature dependent (Hamilton et al. 2001).

The predominance of $C$. hirundinella during dam destratification in March could also be linked to increases in $\mathrm{Si}$ concentrations (Table 2) and may be because this element is a major constituent of $C$. hirundinella cell walls (Sigee et al. 1999). Furthermore, in the current study, a negative relationship was observed between the dominance of $C$. hirundinella (a slow-growing inedible algae) and the lower measured phosphate concentrations in the months March, April and May, which most likely indicated that the higher abundance of this species was associated with low concentrations of phosphate (P) enrichment (Willen 1991; Reynolds et al. 2002). On the other hand, higher concentrations of phosphate by the end of June caused the absence of this species. Supporting evidence for these findings comes from Pollingher (1988). Padisák (1985) reported that at higher phosphate concentrations, $C$. hirundinella abundance was suppressed, while a study by Watson et al. (1997) showed that dinoflagellates have low average biomass in oligotrophic systems and increase rapidly with an increase in phosphates in meso-eutrophic lakes.

The dominance of the diatom $M$. varians (favored by higher growth rates and lower sinking losses) during the months of July and August, may be due to low surface water temperatures (Corbelas and Rojo 1994). A study conducted by Peterson and Stevenson (1989) on the Ohio River and six Kentucky tributaries, indicated that the abundant diatom $M$. varians correlated positively with lower surface water temperatures, while van Dam et al. (1994) suggested that this diatom species is an indicator of eutrophic to hypertrophic water conditions. As illustrated in Table 2, the diatom $M$. varians was the only diatom that was dominant during the months of July and August, while other species were only present during that sampling period. This phenomenon was likely not related to a shortage of $\mathrm{Si}$, as Willen (1991) stated that $\mathrm{Si}$ concentrations as low as $0.2 \mathrm{mg}^{-1}$ should be sufficient for diatom reproduction. Therefore, it seems unlikely that it was the reason for the low dominance of diatoms, but rather the concentrations of $\mathrm{Cl}$ that have adverse effects on the development of diatom species (Willen 1991).

There exists a noticeable difference in the cell-specific rates of nutrient-uptake and the external concentrations to saturate each of the different phytoplankton species (Nalewajko 1958). Consequently, the uptake of nutrients by certain phytoplankton species is faster than others (i.e., they are affinity-adapted). This implies that performance characteristics of nutrient uptake did not just differ among phytoplankton species but among the various nutrients as well. Some 
phytoplankton species can function better than others at lower concentrations of one nutrient (i.e., silica) but may be less capable of taking up another (i.e., phosphorus). An additional outcome is that when the phytoplankton develops in a natural waterbody where Si or P amounts are consistently or frequently at such low concentrations that one species has a consistent or frequent growth advantage over the other, then in time, it is more likely to become dominant over the other. In dams where the nutrient levels are a growth-sustaining requirement (limited resources), this would be in favor of phytoplankton species which are able to maintain the best net performance against the environmental deficiency. This implies that where $\mathrm{P}$ concentration is significantly below $1-2$ $\mu \mathrm{gl}^{-1} \mathrm{P}$, some phytoplankton species are likely to become the more dominant, whilst others that have a high-affinity and demand for P, will be less frequent. According to Reynolds (1999) the same principle can be applied to dams where the nitrogen concentrations are substantially below 50-100 $\mu \mathrm{gl}^{-1} \mathrm{~N}$. In both cases, outcome is independent on nutrient ratios (Reynolds 1999). During the months of January, November and December, Loskop Dam experienced cyanobacterial blooms and can be classified as a meso-eutrophic dam when the phytoplankton trophic spectrum of Reynolds (1999) was employed as a guideline for trophic status.

\section{Modified Pollution Index}

Although the PILD indicated that the species $S$. armatus, $A$. granulate and $O$. rupestris were less pollution tolerant, previous reports by Taylor et al. (2007) showed that these species are indicators of nutrient enrichment conditions. Therefore, it was evident from the selected variables used in the applied PILD that their low presence over the 12-month period was related to different prevailing environmental conditions and not only to nutrient enrichment. Nevertheless, from the species collected during the study period, the most pollution tolerant species were the diatom $M$. varians (9.94), followed by the dinoflagellate $C$. hirundinella (8.67) and the cyanobacteria M. aeruginosa (8.29). During the month with the lowest PILD value (September), the most dominant species was $C$. erosa. Furthermore, from the data generated in the current study, it was evident that the PILD can successfully gauge the different levels of pollution in a subtropical reservoir over space and time. The selected index also showed flexibility to modification to assess different types of waterbodies, as well as using different indicator species. Jiang and Shen (2003) first used the index to assess protozoan communities in the River Hanjiang, China, while Costro-Roa and Pinilla-Agudelo (2014) modify the index to assess the wetland conditions in Brasilia using diatoms as indicators of pollution. In the current study, we modified the index and used it in a sub-tropical reservoir by employing phytoplankton as indicators organisms. Finally, the PILD met a number of criteria for dam management by providing: (1) A meaningful and accurate representation of the prevailing water quality conditions in the reservoir. (2) A basis for easily collectable field data. (3) Simple interpretable data for non-specialist managers. (4) A single value for each month which can be used to flag water quality problems and lastly, (5) The PILD clearly detected a mixture of pollutants in the surface water.

\section{Conclusion}

Degradation of water quality in dams situated in nature reserves is a global issue and impacts not only negatively on the environment but can also affect ecotourism severely. From the outcome of the PILD employed in this study it was evident that nutrient enrichment from point source pollution of WWTP's and AMD from abandon mines upstream of Loskop Dam, had deteriorated the water quality, causing a change in phytoplankton assemblage to more pollution tolerant species. Furthermore, chemical variables during the sampling period that exceeded the limits of the South African, Canadian, Australia and New Zealand guideline levels were $\mathrm{Zn}, \mathrm{TP}, \mathrm{Cl}, \mathrm{Fe}, \mathrm{Mn}$ and $\mathrm{NH}_{4}$. To improve the water quality of Loskop Dam several measures must be put in place in the upper catchment of Loskop Dam to improve the inflowing of water quality. These include upgrading of overloaded wastewater treatment plants, whilst AMD, from the abandon mines in the area, must be treated using bioremediation measures such as constructed wetlands.

Supplementary Information The online version contains supplementary material available at https://doi.org/10.1007/s41742-021-00315-3.

Acknowledgements This study was supported by a grant received from the Loskop Irrigation board, South Africa.

\section{Compliance with Ethical Standards}

Conflict of interest On behalf of all authors, the corresponding author states that there is no conflict of interest.

\section{References}

American Public Health Association (APHA) American Water Works Association (AWWA) and Water Pollution Control Federation (WPCF) (1992) Standard Methods for the Examination of Water and Wastewater. APHA, Washington

Australian and New Zealand Environmental Conservation Council (ANZECC) (2000) Guidelines for Fresh and Marine Water Quality, vol 1. Australian and New Zealand Environmental Conservation Council, Australia and New Zealand

Bain MB, Harig AL, Loucks DP, Goforth RR, Mills KE (2000) Aquatic ecosystem protection and restoration: advances in methods for assessment and evaluation. Environ Sci Policy 3:89-98 
Bellinger EG, Sigee DC (2010) Freshwater Algae: identification and use as bioindicators. John Wiley \& Sons, Ltd, pp 99-132

Berger WH, Parker FL (1970) Diversity of planktonic foraminifera in deep sea sediments. Science 168:1345-1347

Castro-Roa D, Pinilla-Agudelo G (2014) Periphytic diatom index for assessing the ecological quality of the colombian andean urban wetlands of Bogotá. Limnetica 33(2):297-312

CCME (2012) Canadian water quality guidelines for the protection of aquatic life Introduction. Canadian environmental quality guidelines, Canada

Cerón JC, Grande ML, de la Torre ML, Borrego J, Santisteban M, Valente T (2014) Hydrochemical characterization of an acid mine drainage-affected reservoir: the Sancho Reservoir, Huelva, southwest Spain. Hydrol Sci J 59(6):1213-1224

Corbelas M, Rojo C (1994) Factors influencing the share of planktonic diatoms in Lakes. Algol Stud 74:73-104

Dabrowski J, Oberholster PJ, Dabrowski JM, Le Brasseur L, Gieskes J (2013) Chemical characteristics and limnology of Loskop Dam on the Olifants River (South Africa), in light of recent fish and crocodile mortalities. Water SA 39(5):675-686

Dabrowski JM, Dabrowski J, Hill L, Macmillan P, Oberholster PJ (2014) Fate, transport and effects of pollutants originating from acid mine drainage in the Olifants River. South Africa, River Research and Applications

Dabrowski JM (2014D) Applying SWAT to predict orto-phosphate loads in the upper Olifants catchment. Hydrol Earth Syst Sci 18:2629-2643

Dallas HF, Day JA (1993) The effect of water quality variables on riverine ecosystems: a review. WRC Special Report, Pretoria, South Africa

Department of Water Affairs and Forestry (DWAF) (1996) South African water quality guidelines 72 aquatic systems. Department of Water Affairs and Forestry, Pretoria, South Africa

Grobler DC, Kempster PL, van der Merwe L (1994) A note on the occurrence of metals in the Olifants River, Eastern Transvaal, South Africa. Water SA 20:195-205

Hamilton DP, Spillman C, Prescott KL, Kratz TK, Magnuson JJ (2001) Effects of atmospheric nutrient input on trophic status of Crystal Lake, Wisconsin. Verhandlungen des Internat Verein Limnol 28:467-470

Hardin G (1960) The competitive exclusion theory. Science 131:1292-1297

Jiang J, Shen Y (2003) Development of a biotic index using the correlation of protozoan communities with chemical water quality. NZ J Mar Freshwat Res 37:777-792

Johnson JD, Jolley RL (1990) Water chlorination: the challenge. In: Jolley RL, Condie LW, Johnson JD, Katz S, Minear RA, Mattice JS, Jacobs VA (eds) Water chlorination chemistry, environmental impact and health effects. Lewis Publishers, London

Kelly MG, Whitton BA (1995) The Trophic Diatom Index: a new index for monitoring eutrophication in rivers. J Appl Phycol 7(4):433-444

Kruger GHJ, Eloff JN (1978) The effects of temperature on specific growth rate and activation energy of Microcystis and Snechococcus isolates relevant to the onset of natural blooms. J Limnol Soc Southern Africa 4:9-20

Kumar A, Cabral-Pinto M, Kumar A, Dinis KM (2020a) Estimation of risk to the eco-environment and human health of using heavy metals in the Uttarakhand Himalaya. India Appl Sci 10:7078

Kumar A, Mishra S, Taxak A, Pandey R, Yu Z (2020b) Nature rejuvenation: Long-term (1989-2016) vs short-term memory approach based appraisal of water quality of the upper part of Ganga River India. Environ Technol Innov 20:101164

Kumar A, Kumar A, Chaturvedi AK, Shabnam AA, Subrahmanyam G, Mondal R, Gupta DK, Malyan SK, Kumar SS, Khan SA, Yadav KK (2020c) Lead toxicity: health hazards, influence on food chain, and sustainable remediation approaches. Internat $\mathrm{J}$ Environ Res Pub Health 17:2179

Kumari P, Dhadse S, Chaudhari P R, Wate S R (2008) A biomonitoring of plankton to assess quality of water in the lakes of Nagpur City. The 12th World Lake Conference 160-164.

Lally H, Gormally M, Higgins T, Gammell M, Colleran E (2012) Phytoplankton assemblage in four on cutaway peatlands in Ireland. Royal Irish Acad 112(2):207-216

Lebepe J, Oberholster PJ, Ncube I, Smit W, Luus-Powell WJ (2020) Metal levels in two fish species from a waterbody impacted by metallurgic industries and acid mine drainage from coal mining in South Africa. J Environ Sci Health 55(4):421-432

McCullough CD, Lund MA, May JM (2008) Field-scale demonstration of the potential for sewage to remediate acidic mine waters. Mine Water Environ 27:31-39

Mishra S, Sharma M, Kumar A (2016) Assessment of surface water quality in Surha Lake using a pollution index, India. J Mater Environ Sci 7:713-719

Nalewajko C (1978) Release of organic substances. In: Hellebust JA, Craige JS (eds) Handbook of phycological methods physiological and biochemical methods. Cambridge University Press, Cambridge

Oberholster PJ, Myburgh JG, Ashton PJ, Botha A-M (2010) Responses of phytoplankton upon exposure to a mixture of acid mine drainage and high levels of nutrient pollution in Lake Loskop, South Africa. Ecotoxicol Environ Saf 73:326-335

Oberholster PJ, Botha AM, Chamier J, de Klerk A (2013) Longitudinal trends in water chemistry and phytoplankton assemblage downstream of the Riverview WWTP in the Upper Olifants River. Ecohydrol Hydrobiol 13:41-51

Oberholster PJ, Botha AM, Hill L, Strydom WF (2017) River catchment responses to anthropogenic acidification in relationship with sewage effluent: an ecotoxicology screening application. Chemosphere 189:407-417

Padisák J (1985) Population dynamics of the freshwater dinoflagellate Ceratium hirundella in the largest shallow lake of Central Europe, Lake Balaton, Hungary. Freshw Biol 15:43-52

Palmer CM (1969) A composite rating of algae tolerating organic pollution. J Phytocol 5:78-82

Peine A, Peiffer S (1998) In-lake neutralization of acid mine lakes. In: Geller W, Klapper H, Salomons W (eds) Acidic mining lakes: acid mine drainage, limnology and reclamation. Springer Verlag, Berlin

Peterson CG, Stevenson RJ (1989) Seasonality in river phytoplankton: multivariate analyses of data from the Ohio River and Kentucky tributaries. Hydrobiologia 182(2):99-114

Pollingher U (1988) Freshwater dinoflagellates: Growth, reproduction strategies and population dynamics. In: Sandgren C (ed) Growth and reproductive strategies of freshwater phytoplankton. University of Cambridge, Cambridge, pp 134-174

Reynolds CS (1984) Phytoplankton periodicity: the interactions of form, function and environmental variability. Freshw Biol $14: 111-142$

Reynolds CS (1999) Phytoplankton assemblages in reservoirs. In: Tundisi JG, Straškraba M (eds) Theoretical Reservoir Ecology and its Applications. Backhuys, Leiden, pp 439-456

Reynolds CS, Huszar VLM, Kruk C, Naselli-Flores L, Melo S (2002) Towards a functional classification of the freshwater phytoplankton. J Plankton Res 24:417-428

Roetman ET (1932) The sterilization of sewage by acid mine water. M.S. thesis. West Virginia University, Morgantown

Shaw PJA (2003) Multivariate statistics for environmental science. Arnold Publishers, London

Sigee DC, Levado E, Dodwell AJ (1999) Elemental composition of depth samples of Ceratium hirundinella (Pyrrophyta) within a 
stratified lake: an X-ray microanalytical study. Aquat Microb Ecol 19:177-187

Sládeček V (1986) Diatoms as indicators of organic pollution. Acta Hydrochim Hydrobiol 14(5):555-566

Strosnider WH, Nairn RW (2011) Effective passive treatment of highstrength acid mine drainage and raw municipal wastewater in Potosi, Bolivia using simple mutual incubations and limestone. J Geochem Explor 105:34-42

Strosnider WH, Winfrey BK, Nairn RW (2011) Biochemical oxygen demand and nutrient processing in a novel multi-stage raw municipal wastewater and acid mine drainage passive co-treatment system. Water Res 45:1079-1086

SYSTAT (1997) Systat 7.0.1 for windows statics. SPSS Inc, Chicago

Taylor JC, Harding WR, Archibald CGM (2007) An illustrated guide to some common diatom species from South Africa WRC Report, No TT 282/07. Water Research Commission, Pretoria, South Africa

Tm LK, Lund JWG, Kipling C, Le Cren EO (1958) The inverted microscope method of estimating algal numbers and the statistical basis of estimations by counting. Hydrobiology 11:143-170

United States Environmental Protection Agency (USEPA) (1983) Methods for chemical analysis of water and wastes EPA
600/4-79/020. USEPA Environmental Monitoring and Support Laboratory, Cincinnati

van Dam H, Merten A, Sinkeldam J (1994) A coded checklist and ecological indicator value of freshwater diatoms from the Netherlands. Nederland J Aquatic Ecol 28(1):117-133

Van Vuuren S, Taylor JC, Gerber A, Van Ginkel C (2006) Easy identification of the most common freshwater algae. North-West University and Department of Water Affairs and Forestry, Pretoria, pp 1-200

Wehr JD, Sheath RG (2001) Freshwater Algae of North America, ecology and classification. Academic Press, San Diego

Wendt-Potthoff K, Neu TR (1998) In-lake neutralization of acid mine lakes. In: Geller W, Klapper H, Salomons W (eds) Acidic mining lakes: acid mine drainage, limnology and reclamation. Springer, Berlin, pp 269-284

White GC (1992) The handbook of chlorination and alternative disinfectants, 3rd edn. Van Nostrand Reinhold, New York

Willen E (1991) Planktonic diatoms - an ecological review. Algol Stud 62:69-106

Wurts W, Durborow R (1992) Interaction of carbon dioxide, $\mathrm{pH}$, alkalinity and hardness in fish ponds. Southern regional aquaculture centre, Stoneville 